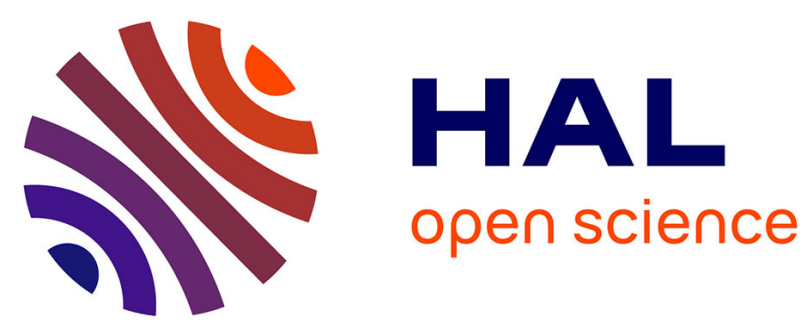

\title{
Synthesis, Fluorescence and Two-Photon Absorption Properties of Multichromophoric Boron-Dipyrromethene Fluorophores for Two-Photon-Excited Fluorescence Applications
}

\author{
Laurent Porrès, Olivier Mongin, Mireille Blanchard-Desce
}

\section{To cite this version:}

Laurent Porrès, Olivier Mongin, Mireille Blanchard-Desce. Synthesis, Fluorescence and TwoPhoton Absorption Properties of Multichromophoric Boron-Dipyrromethene Fluorophores for TwoPhoton-Excited Fluorescence Applications. Tetrahedron Letters, 2006, 47 (12), pp.1913-1917. 10.1016/j.tetlet.2006.01.087 . hal-00785010

\author{
HAL Id: hal-00785010 \\ https://hal.science/hal-00785010
}

Submitted on 5 Feb 2013

HAL is a multi-disciplinary open access archive for the deposit and dissemination of scientific research documents, whether they are published or not. The documents may come from teaching and research institutions in France or abroad, or from public or private research centers.
L'archive ouverte pluridisciplinaire HAL, est destinée au dépôt et à la diffusion de documents scientifiques de niveau recherche, publiés ou non, émanant des établissements d'enseignement et de recherche français ou étrangers, des laboratoires publics ou privés. 
Synthesis, Fluorescence and Two-photon Absorption Properties of Multichromophoric Boron-Dipyrromethene Fluorophores for TwoPhoton-Excited Fluorescence Applications

Laurent Porrès, Olivier Mongin, Mireille Blanchard-Desce*

Synthèse et ElectroSynthèse Organiques (CNRS, UMR 6510), Université de Rennes 1, Institut de Chimie, Campus Scientifique de Beaulieu, Bât 10A, F-35042 Rennes, France

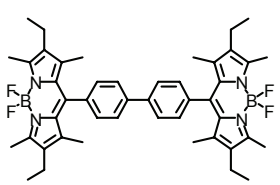

$\phi=0.72, \tau=4.76 \mathrm{~ns}$ $\sigma_{2}=57 \mathrm{GM}$ at $705 \mathrm{~nm}$

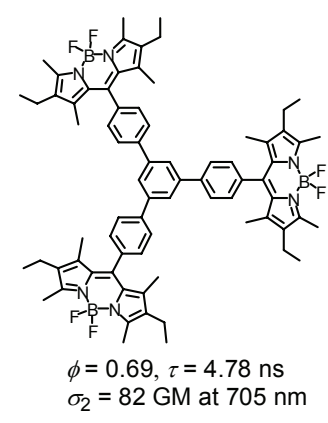




\title{
Synthesis, Fluorescence and Two-Photon Absorption Properties of Multichromophoric Boron-Dipyrromethene Fluorophores for Two-Photon-Excited Fluorescence Applications
}

\author{
Laurent Porrès, ${ }^{\dagger}$ Olivier Mongin, Mireille Blanchard-Desce* \\ Synthèse et ElectroSynthèse Organiques (CNRS, UMR 6510), Université de Rennes 1, Institut de Chimie, Campus \\ Scientifique de Beaulieu, Bât 10A, F-35042 Rennes, France
}

\begin{abstract}
The synthesis and the characterization of new multichromophoric boron-dipyrromethene dyes are described. Their absorption, photoluminescence as well as their two-photon absorption properties have been investigated. This work shows that assembling several dyes in conjugated multichromophoric structures is a promising strategy for improving the two-photon absorption properties of such fluorophores in the NIR region while retaining their excellent photoluminescence properties.
\end{abstract}

For more than a decade, two-photon absorption (TPA) has attracted increasing attention in relation with various applications, such as $3 \mathrm{D}$ microfabrication ${ }^{1}$ and optical data storage, ${ }^{2}$ photodynamic therapy, ${ }^{3}$ and optical power limiting. ${ }^{4}$ Moreover, two-photon-excited fluorescence (TPEF) has been found to be of particular interest for the biology community: two-photon laser scanning fluorescence microscopy (TPEFLSM) offers the advantages of imaging deeper in living tissues (down to $500 \mu \mathrm{m}$ ), with reduced photodamages and background fluorescence and with sharp 3D spatial resolution. ${ }^{5}$ The advantages of TPEFLSM call for the design of new fluorophores whose TPA cross-sections are optimized in the spectral range of interest for biological imaging (700-1200 nm). Indeed designing molecular fluorophores with much higher TPA crosssection than endogenous chromophores ${ }^{6}$ and conventional fluorophores such as fluorescein or rhodamine, ${ }^{7}$ would allow to reduce the concentration of fluorophores and molecular markers and/or the excitation intensity, which is highly desirable for biological imaging. ${ }^{8}$ Key parameters for the design of new TPE-fluorophores and markers for biological imaging are high fluorescence quantum yield $\Phi$ and very large TPA cross-section $\left(\sigma_{2}\right)$. In addition excellent photostability and low (photo)toxicity are required.

Boron-dipyrromethene dyes (Figure 1) belong to a modern class of fluorophores showing attractive properties: tunable photoluminescence in the 500-650 $\mathrm{nm}$ spectral range, high fluorescence quantum yield in various media (including water in the case of water-soluble derivatives), long enough fluorescence lifetime (about $5 \mathrm{~ns}$ ). ${ }^{10-20}$ In addition, both hydrophilic and lipophilic derivatives can be prepared via grafting of suitable side groups on the pyrrole moieties. Boron-dipyrromethene fluorophores have been used in fluorescent probes for various applications including cation sensing, ${ }^{21}$ ionofluorophores, ${ }^{22}$ dosimetric reagents, ${ }^{23}$ monitoring of bioactivity (NO imaging), ${ }^{24}$ live-cell imaging ${ }^{25}$ and even in TPEF-based fluorimmunoassays. ${ }^{26}$ However, these compounds have not yet been optimized for TPA and their TPEF crosssections remain low. ${ }^{7}$ In this paper, we describe the strategy that we have implemented towards improved TPEF.

Keywords: two-photon-excited fluorescence (TPEF); multichromophores; photoluminescence; BODIPY ${ }^{\circledR}$.

* Corresponding author. Tel: +33 2 23236277; fax: +33 223236277; e-mail: mireille.blanchard-desce@univ-rennes1.fr

† Present address: Department of Chemistry, University of Durham, South Road, Durham, DH1 3LE, UK. 


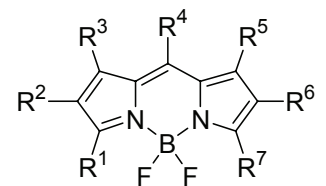

BODIPY

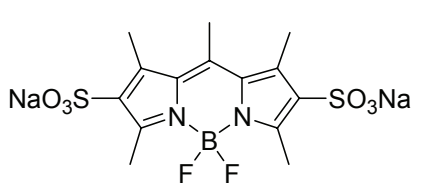

PM556

Figure 1. Left: general structure of boron-dipyrromethenes (BODIPY ${ }^{\circledR}$ ).

Right: structure of water-soluble 4,4-difluoro-1,3,5,7,8-pentamethyl-4bora-3a,4a-diaza-s-indacene-2,6-disulfonic acid, disodium salt ${ }^{27}$ (PM556).

Our approach is based on the design of multichromophoric boron-dipyrromethene assemblies, where dyes moieties are assembled in defined geometries by using conjugated rigid spacers (Scheme 1). Although much work has been carried out in the past on multichromophoric assemblies in the field of second-order nonlinear optics, ${ }^{28}$ the mutichromophoric strategy is very recent in the field of TPA. ${ }^{29,30}$

Based on our earlier work on the design of nanoscale elongated quadrupolar and octupolar derivatives built from either a bipheny $1^{31}$ or a triphenylbenzene ${ }^{30,32}$ core and displaying giant TPA cross-sections, we chose to use biphenyl and triphenylbenzene as rigid spacers connecting the boron-dipyrromethene fluorophores. However, in contrast to our previous work, we chose to focus on short derivatives to maintain compact size/volume. In addition we did not introduce ethynylene or vinylene intermediary linkers to ensure high photostability. Hereafter, we will describe the synthesis, photoluminescence and TPA properties of such bis-chromophoric and tris-chromophoric derivatives. An important issue is to investigate how the approach implemented here affects the photoluminescence and TPA properties.

The bis-chromophoric dye 3 was synthesized from (1,1'-biphenyl)-4,4'-dicarboxaldehyde ${ }^{33}$ (2) and 4 equiv of 2,4-dimethyl-3-ethylpyrrole (1) (Scheme 1). The synthesis proceeds in three steps: first addition of TFA to the mixture of aldehyde and pyrrole to give in situ the corresponding dipyrromethane, then conversion of the latter into dipyrromethene by oxidation with DDQ, and finally treatment with an excess of trifluoroboron-etherate in the presence of base to afford the corresponding boron complex. The trischromophoric dye 5 was prepared by reacting the trialdehyde $4^{34}$ with 6 equiv of the pyrrole 1 (Scheme 1), using the same procedure than for $\mathbf{3}$. The new fluorophores $\mathbf{3}$ and $\mathbf{5}$ have been fully characterized by NMR and HRMS. $^{35}$ 

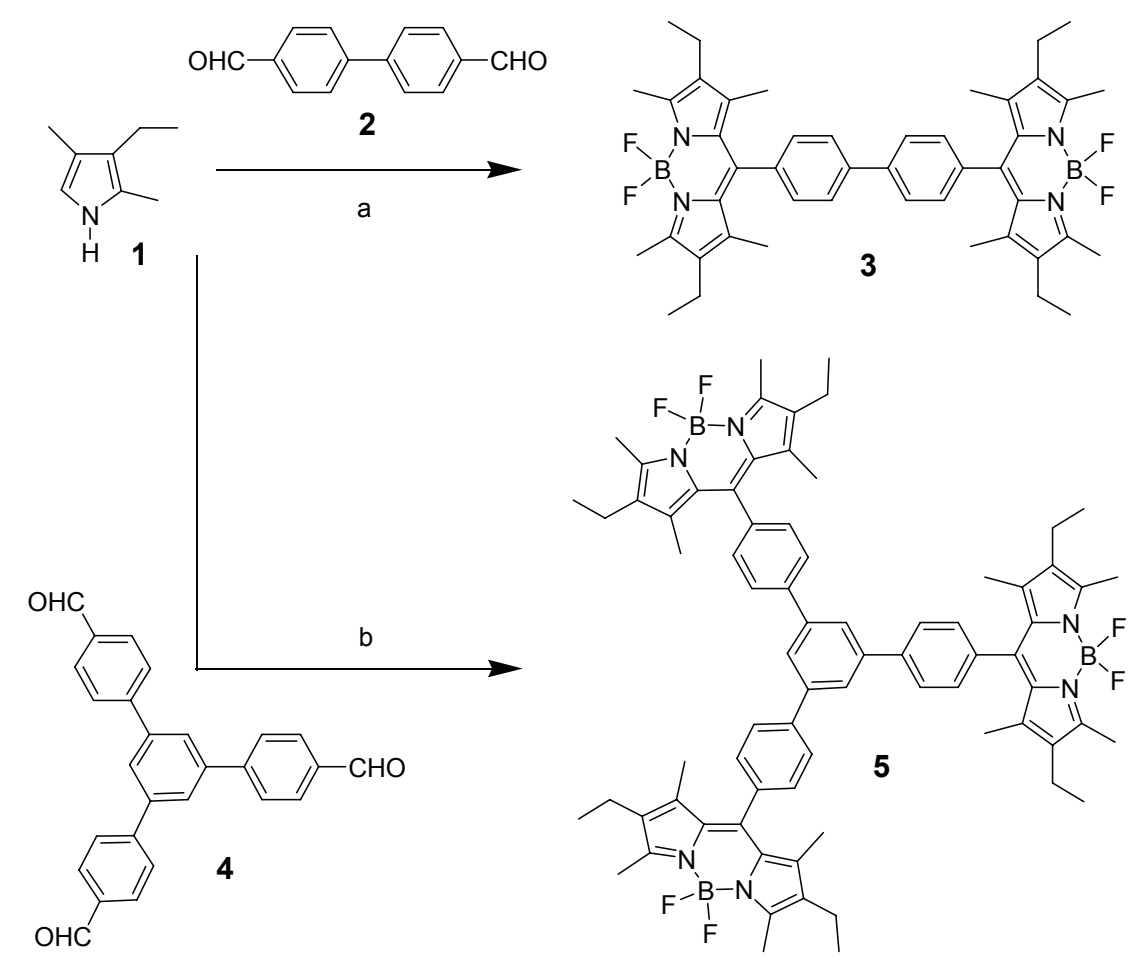

Scheme 1. Reagents and conditions: (a) 1 (4 equiv), 2 (1 equiv), TFA, $\mathrm{CH}_{2} \mathrm{Cl}_{2}, \mathrm{rt}$, $2 \mathrm{~h}$, then DDQ (2 equiv), rt, $1 \mathrm{~h}$, then $i$ - $\mathrm{Pr}_{2} \mathrm{NEt}, \mathrm{BF}_{3}-\mathrm{Et}_{2} \mathrm{O}$ (excess), rt, $1 \mathrm{~h}$ (overall yield 42\%); (b) 1 (6 equiv), 4 (1 equiv), TFA, $\mathrm{CH}_{2} \mathrm{Cl}_{2}, \mathrm{rt}, 2 \mathrm{~h}$, then DDQ (3 equiv), $\mathrm{rt}, 1 \mathrm{~h}$, then $i$ - $\mathrm{Pr}_{2} \mathrm{NEt}, \mathrm{BF}_{3}-\mathrm{Et}_{2} \mathrm{O}$ (excess), rt, $1 \mathrm{~h}$ (overall yield $23 \%$ ).

The absorption and photoluminescence characteristics (including fluorescence quantum yields and fluorescence lifetimes) of the series of dyes are gathered in Table 1. As illustrated in Figure 2, chromophores 3 and 5 exhibit an intense and sharp absorption band in the visible region. Both dyes present similar photophysical properties. Both the energy absorption and emission band peaks are at the same wavelength, and absorption and emission bands show identical width and vibronic structure. In addition, the molar extinction coefficients were found to increase linearly with the number of boron-dipyrromethene chromophores while the fluorescence quantum yields and lifetimes remain the same (Table 1). This indicates that the excitation energy is localized on the boron-dipyrromethene moieties and that emission occurs from these units, thus retaining the excellent photoluminescence properties of the boron-dipyrromethene fluorophores. 
Table 1. One and two-photon photophysical data of fluorophores $\mathbf{3}$ and $\mathbf{5 .}$

\begin{tabular}{|c|c|c|c|c|c|c|c|}
\hline \multirow{2}{*}{ Compd } & \multirow{2}{*}{$\begin{array}{c}\lambda_{\mathrm{abs}} \\
(\mathrm{nm})\end{array}$} & \multirow{2}{*}{$\begin{array}{c}\varepsilon \\
\left(\mathrm{M}^{-1} \cdot \mathrm{cm}^{-1}\right)\end{array}$} & \multirow{2}{*}{$\begin{array}{c}\lambda_{\mathrm{em}} \\
(\mathrm{nm})\end{array}$} & \multirow{2}{*}{$\Phi^{\mathrm{d}}$} & \multirow{2}{*}{$\begin{array}{c}\tau^{\mathrm{e}} \\
(\mathrm{ns})\end{array}$} & \multicolumn{2}{|c|}{$\sigma_{2}(\mathrm{GM})^{\mathrm{f}}$} \\
\hline & & & & & & at $700 \mathrm{~nm}$ & at $990 \mathrm{~nm}$ \\
\hline $3^{\mathrm{a}}$ & 527 & 161900 & 542 & 0.72 & 4.76 & 57 & 48 \\
\hline $5^{\mathrm{a}}$ & 527 & 244300 & 542 & 0.69 & 4.78 & 82 & 75 \\
\hline PM556 ${ }^{\mathrm{b}}$ & $491^{\mathrm{g}}$ & $98600^{\mathrm{g}}$ & $519^{\mathrm{g}}$ & $0.83^{\mathrm{g}}$ & $4.23^{\mathrm{g}}$ & - & $9\left(20^{\mathrm{h}}\right)^{\mathrm{i}}$ \\
\hline Fluorescein ${ }^{c}$ & 491 & 75500 & 515 & 0.90 & & $18^{\mathrm{i}}$ & $13^{\mathrm{i}}$ \\
\hline $\begin{array}{l}{ }^{\mathrm{a}} \text { In toluene. } \\
{ }^{\mathrm{b}} \text { In water. } \\
{ }^{\mathrm{c}} \text { In water, } \mathrm{p} \\
{ }^{\mathrm{d}} \text { Fluorescen } \\
{ }^{\mathrm{e}} \text { Experimen } \\
{ }^{\mathrm{f}} \text { TPA cross- } \\
\text { performed u } \\
\text { MHz, calibr } \\
{ }_{\mathrm{g}} \text { Data from } \\
{ }^{\mathrm{h}} \text { TPA cross } \\
{ }^{\mathrm{i}} \text { Data from }\end{array}$ & $\begin{array}{l}\text { I } 11 . \\
\text { e quant } \\
\text { al fluor } \\
\text { ections } \\
\text { ing a m } \\
\text { ted witl } \\
\text { t. } \\
\text { ection }\end{array}$ & $\begin{array}{l}\text { m yield dete } \\
\text { cence lifetin } \\
1 \mathrm{GM}=10^{-5} \\
\text { de-locked Ti } \\
\text { fluorescein. } \\
920 \mathrm{~nm} .\end{array}$ & $\begin{array}{l}\text { ained } \mathrm{re} \\
\text { using } \\
\mathrm{m}^{4} . \mathrm{s} . \mathrm{pl} \\
\text { apphire }\end{array}$ & $\begin{array}{l}\text { tive to } \\
\text { ne-corr } \\
\text { ton }^{-1} ; \mathrm{T} \\
\text { aser de }\end{array}$ & $\begin{array}{l}\text { luores } \\
\text { lated s } \\
\text { PEF m } \\
\text { vering }\end{array}$ & $\begin{array}{l}\text { ein in } 0.1 \mathrm{~N} \\
\text { ngle photon } \\
\text { asurements } \\
80 \text { fs pulses }\end{array}$ & $\begin{array}{l}\mathrm{NaOH} . \\
\text { counting. } \\
\text { were } \\
\text { at } 80\end{array}$ \\
\hline
\end{tabular}

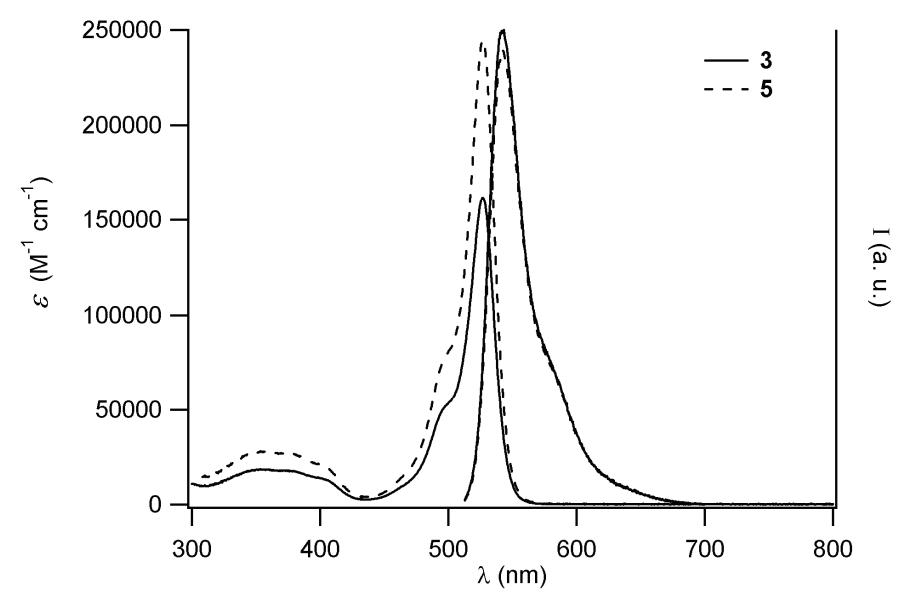

Figure 2. Absorption and fluorescence emission spectra of dyes $\mathbf{3}$ and 5 in toluene.

The TPA spectra of multichromophoric dyes 3 and 5 (Figure 3) were determined in the NIR range (700-1000 nm) by investigating the two-photon-excited fluorescence (TPEF) in $10^{-4} \mathrm{M}$ toluene solutions using a mode-locked Ti:sapphire laser delivering $80 \mathrm{fs}$ pulses at $80 \mathrm{MHz}$, following the experimental protocol described by Xu and Webb. ${ }^{7}$ The quadratic dependence of the fluorescence intensity on the excitation intensity was verified for every data point. TPEF measurements were calibrated relative to the absolute TPEF action cross-sections determined by Xu and Webb for fluorescein in water $(\mathrm{pH}=11)$ in the $690-1000 \mathrm{~nm}$ range. ${ }^{7,36}$ This procedure provides the TPEF action cross-section $\sigma_{2} \phi$ from which the corresponding $\sigma_{2}$ value is derived. Selected data are included in Table 1. Literature TPA data for PM556 and fluorescein ${ }^{7}$ are also shown for comparison. 


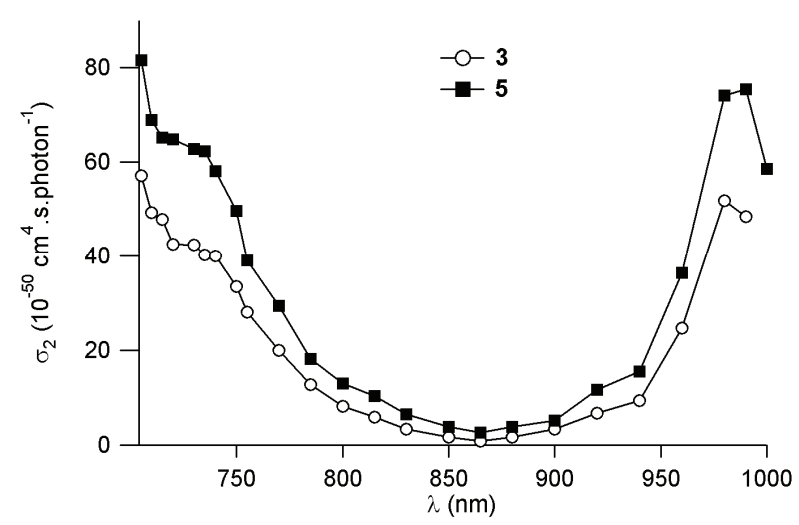

Figure 3. TPA spectra of dyes $\mathbf{3}$ and $\mathbf{5}$ in toluene.

The TPA cross-sections of bis-chromophoric dye $\mathbf{3}$ and tris-chromophoric dye $\mathbf{5}$ were found to be of 48 and $75 \mathrm{GM}$ at $990 \mathrm{~nm}$, respectively, which correspond to about 2.4 and 3.7 times that of PM556 at its maximum $\left(\sigma_{2}{ }^{\max }=20 \mathrm{GM}\right.$ at $\left.920 \mathrm{~nm}\right)$. This reveals a reasonable increase $(20 \%$ for 3 and $25 \%$ for $\mathbf{5})$ of the lower energy TPA maxima in the assemblies as compared to the additional contribution of two or three independent PM556 chromophores. More importantly, we observe the emergence of a new and more intense TPA band at lower wavelength that is not present in the TPA spectrum of the reference boron-dipyrromethene dye. ${ }^{7}$ As a result multichromophoric fluorophores $\mathbf{3}$ and $\mathbf{5}$ show much larger TPA cross-section at $700 \mathrm{~nm}$ than single boron-dipyrromethene dyes. This higher energy two-photon excitation band responsible for the marked TPA enhancement at $700 \mathrm{~nm}$ is most probably related to the presence of the biphenyl and triphenylbenzene linkers (in relation with the weakly one-photon allowed absorption band observed at $350 \mathrm{~nm}$ ). It should be stressed however that the TPA cross-section of both the biphenyl or triphenyl benzene moieties and of the boron-dipyrromethene are quite low at $700 \mathrm{~nm}$ emphasizing that the combination of these conjugated linkers with the boron-dipyrromethene moieties leads to a cooperative enhancement of the TPA responses as compared to an additive behavior. The modular multichromophoric strategy implemented here thus opens an interesting route for TPA enhancement and could be extended to other types of conjugated connectors, including dendrimers.

In conclusion, the multichromophoric approach based on the grafting of multiple borondipyrromethene fluorophores on suitable cores that act as two-photon absorption enhancers is indicating that the multichromophoric approach is a valid strategy for improving the TPA properties. This novel approach towards improved TPEF labels and probes offers several advantages because it allows retaining the excellent characteristics of the boron-dipyrromethene fluorescent units while taking advantage of the connectors for TPA modulation and enhancement. This leaves space for further engineering and spectral tuning of the TPEF properties in multichromophoric assemblies. In particular the molecular engineering routes for optimization of the TPA properties of quadrupoles ${ }^{31,37}$ and octupoles ${ }^{38}$ could be successfully applied for the design of optimized multichromophoric architectures. Furthermore it would be interesting to assemble a large number of chromophoric units in dendritic structures where the dendritic core could serve as a TPA enhancer.

\section{Acknowledgements}

This work was supported in part by the Centre National de la Recherche Scientifique and Rennes Métropole. L.P. received a fellowship from the French Ministère de 1'Education Nationale, de l'Enseignement Supérieur 
et de la Recherche. We are very grateful to T. Pons and Prof. J. Mertz for access to their TPEF facilities. We also wish to thank M. H. V. Werts for expert help in TPEF experiments.

\section{References}

1. (a) Kawata, S.; Sun, H.-B.; Tanaka, T.; Takada, K. Nature 2001, 412, 697-698; (b) Zhou, W.; Kuebler, S. M.; Braun, K. L.; Yu, T.; Cammack, J. K.; Ober, C. K.; Perry, J. W.; Marder, S. R. Science 2002, 296, 1106-1109.

2. (a) Parthenopoulos, D. A.; Rentzepis, P. M. Science 1989, 245, 843-845; (b) Strickler, J. H.; Webb, W. W. Opt. Lett. 1991, 16, 1780-1782.

3. Bhawalkar, J. D.; Kumar, N. D.; Zhao, C. F.; Prasad, P. N. J. Clin. Laser Med. Surg. 1997, 15, 201-204.

4. (a) He, G. S.; Xu, G. C.; Prasad, P. N.; Reinhardt, B. A.; Bhatt, J. C.; Dillard, A. G. Opt. Lett. 1995, 20, 435-437; (b) Ehrlich, J. E.; Wu, X. L.; Lee, I.-Y. S.; Hu, Z.-Y.; Röckel, H.; Marder, S. R.; Perry, J. W. Opt. Lett. 1997, 22, $1843-1845$.

5. Denk, W.; Strickler, J. H.; Webb, W. W. Science 1990, 248, 73-76.

6. Xu, C.; Zipfel, W.; Shear, J. B.; Williams, R. M.; Webb, W. W. Proc. Natl. Acad. Sci. U. S. A. 1996, 93, $10763-10768$.

7. Xu, C.; Webb, W. W. J. Opt. Soc. Am. B 1996, 13, 481-491.

8. Semiconducting nanoparticles have been shown to lead to giant TPA cross-sections ${ }^{9}$ and show excellent photostability, but they have several drawbacks (toxicity and size) for biological imaging.

9. Larson, D. R.; Zipfel, W. R.; Williams, R. M.; Clark, S. W.; Bruchez, M. P.; Wise, F. W.; Webb, W. W. Science 2003, 300, 1434-1437.

10. Haugland, R. P.; Kang, H. C. (Molecular Probes, Inc., USA), U.S. Patent 4,774,339 (1988).

11. Wagner, R. W.; Lindsey, J. S. Pure Appl. Chem. 1996, 68, 1373-1380.

12. Li, F.; Yang, S. I.; Ciringh, Y.; Seth, J.; Martin, C. H., III; Singh, D. L.; Kim, D.; Birge, R. R.; Bocian, D. F.; Holten, D.; Lindsey, J. S. 1998.

13. López Arbeloa, T.; López Arbeloa, F.; López Arbeloa, I.; García-Moreno, I.; Costela, A.; Sastre, R.; F., A.-G. Chem. Phys. Lett. 1999, 299, 315-321.

14. López Arbeloa, T.; López Arbeloa, F.; López Arbeloa, I. Phys. Chem. Chem. Phys. 1999, 1, 791-795.

15. Chen, J.; Burghart, A.; Wan, C.-W.; Thai, L.; Ortiz, C.; Reibenspies, J.; Burgess, K. Tetrahedron Lett. 2000, 41, 23032307.

16. Rurack, K.; Kollmannsberger, M.; Resch-Genger, U.; Daub, J. J. Am. Chem. Soc. 2000, 122, 969-969.

17. Bergström, F.; Mikhalyov, I.; Hägglöf, P.; Wortmann, R.; Ny, T.; Johansson, L. B.-Å. J. Am. Chem. Soc. 2001, 124, 196204.

18. Rurack, K.; Kollmannsberger, M.; Daub, J. Angew. Chem., Int. Ed. 2001, 40, 385-387.

19. Wan, C.-W.; Burghart, A.; Chen, J.; Bergström, F.; Johansson, L. B.-Å.; Wolford, M. F.; Kim, T. G.; Topp, M. R.; Hochstrasser, R. M.; Burgess, K. Chem. Eur. J. 2003, 9, 4430-4441. Ulrich, G.; Ziessel, R. Tetrahedron Lett. 2004, 2004, 1949-1953.

Goze, C.; Ulrich, G.; Charbonnière, L.; Cesario, M.; Prangé, T.; Ziessel, R. Chem. Eur. J. 2003, 9, 3748-3755.

Cha, N. R.; Moon, S. Y.; Chang, S.-K. Tetrahedron Lett. 2003, 44, 8265-8268.

Coskun, A.; Akkaya, E. U. Tetrahedron Lett. 2004, 45, 4947-4949.

Gabe, Y.; Urano, Y.; Kikuchi, K.; Kojima, H.; Nagano, T. J. Am. Chem. Soc. 2004, 126, 3357-3367.

Reents, R.; Wagner, M.; Kuhlmann, J.; Waldmann, H. Angew. Chem., Int. Ed. 2004, 43, 2711-2714.

Meltola, N. J.; Soini, A. E.; Hänninen, P. E. J. Fluoresc. 2004, 14, 129-138.

D-3238 from Molecular Probes.

(a) Rekai, E. D.; Baudin, J.-B.; Jullien, L.; Ledoux, I.; Zyss, J.; Blanchard-Desce, M. Chem. Eur. J. 2001, 7, 4395-4402; (b) Kenis, P. J. A.; Noordman, O. F. J.; Houbrechts, S.; Van Hummel, G. J.; Harkema, S.; Van Veggel, F. C. J. M.; Clays, K.; Engbersen, J. F. J.; Persoons, A.; Van Hulst, N. F.; Reinhoudt, D. N. J. Am. Chem. Soc. 1998, 120, 7875-7883; (c) Goovaerts, E.; Wenseleers, W. E.; Garcia, M. H.; Cross, G. H. In Handbook of Advanced Electronic and Photonic Materials and Devices; Nalwa, H. S. Ed.; Academic Press: New York, 2001; Vol. 9: Nonlinear Optical Materials; pp. 127191, and references cited therein.

29. (a) Adronov, A.; Fréchet, J. M. J.; He, G. S.; Kim, K.-S.; Chung, S.-J.; Swiatkiewicz, J.; Prasad, P. N. Chem. Mater. 2000, 12, 2838-2841; (b) Drobizhev, M.; Karotki, A.; Rebane, A.; Spangler, C. W. Opt. Lett. 2001, 26, 1081-1083; (c) Drobizhev, M.; Stepanenko, Y.; Dzenis, Y.; Karotki, A.; Rebane, A.; Taylor, P. N.; Anderson, H. L. J. Am. Chem. Soc. 2004, 126, 15352-15353.

30. Mongin, O.; Brunel, J.; Porrès, L.; Blanchard-Desce, M. Tetrahedron Lett. 2003, 44, 2813-2816.

31. (a) Ventelon, L.; Charier, S.; Moreaux, L.; Mertz, J.; Blanchard-Desce, M. Angew. Chem., Int. Ed. 2001, 40, 2098-2101; (b) Mongin, O.; Porrès, L.; Moreaux, L.; Mertz, J.; Blanchard-Desce, M. Org. Lett. 2002, 4, 719-722; (c) Silly, M. G.; Porrès, L.; Mongin, O.; Chollet, P.-A.; Blanchard-Desce, M. Chem. Phys. Lett. 2003, 379, 74-80. 
35. Experimental procedures and selected data for:

Tetrafluoro[ $\mu$-[2,2'-[(1,1'-biphenyl)-4,4'-diylbis[[4-ethyl-3,5-dimethyl-2H-pyrrol-2-ylidene-]methylene]]bis[4-ethyl3,5-dimethyl-1H-pyrrolato]lldiboron (3). To a solution of 2,4-dimethyl-3-ethylpyrrole (367.4 mg, $3 \mathrm{mmol}$ ) and 4,4'biphenyldicarboxaldehyde (158 mg, $0.75 \mathrm{mmol})$ in anhydrous $\mathrm{CH}_{2} \mathrm{Cl}_{2}(95 \mathrm{~mL})$ was added one drop of TFA. The mixture was stirred for $2 \mathrm{~h}$ and a solution of DDQ $(340.5 \mathrm{mg}, 1.5 \mathrm{mmol})$ in anhydrous $\mathrm{CH}_{2} \mathrm{Cl}_{2}(45 \mathrm{~mL})$ was added. After stirring for $1 \mathrm{~h}$, diisopropylethylamine $(3 \mathrm{~mL}, 17.2 \mathrm{mmol})$ then $\mathrm{BF}_{3}-\mathrm{Et}_{2} \mathrm{O}(3 \mathrm{~mL}, 23.7 \mathrm{mmol})$ were added. The solution was stirred for $1 \mathrm{~h}$ and water $(100 \mathrm{~mL})$ was added. After filtration of the organic layer through a short pad of silica, the solvent was evaporated and the product purified by column chromatography (heptane $/ \mathrm{CH}_{2} \mathrm{Cl}_{2} 3: 2$ ) to yield $240 \mathrm{mg}(42 \%)$ of 3: $\mathrm{mp}>$ $300{ }^{\circ} \mathrm{C}$ dec.; ${ }^{1} \mathrm{H}$ NMR $\left(200.13 \mathrm{MHz}, \mathrm{CDCl}_{3}\right) \delta 7.82$ and $7.41\left(\mathrm{AA}^{\prime} \mathrm{XX}^{\prime}, J_{\mathrm{AX}}=8.1,8 \mathrm{H}\right), 2.56(\mathrm{~s}, 12 \mathrm{H}), 2.33(\mathrm{q}, J=7.3,8 \mathrm{H})$, $1.39(\mathrm{~s}, 12 \mathrm{H}), 1.00(\mathrm{t}, J=7.3,12 \mathrm{H}) ;{ }^{13} \mathrm{C} \mathrm{NMR}\left(50.32 \mathrm{MHz}, \mathrm{CDCl}_{3}\right) \delta 153.7,140.3,139.5,138.1,135.1,132.6,130.6$, 128.8, 127.3, 17.9, 14.4, 12.3, 11.8; HRMS (LSIMS ${ }^{+}$, mNBA) cacld for $\mathrm{C}_{46} \mathrm{H}_{52} \mathrm{~B}_{2} \mathrm{~F}_{4} \mathrm{~N}_{4}\left(\mathrm{M}^{+}\right.$) $\mathrm{m} / \mathrm{z} 758.4314$, found 758.4335 .

Hexafluoro[ $\mu_{3}-\left[2,2^{\prime}, 2^{\prime \prime}-[1,3,5\right.$-benzenetriyltris[4,1-phenylene[[4-ethyl-3,5-dimethyl-2H-pyrrol-2-

ylidene]methylene]]tris[4-ethyl-3,5-dimethyl-1 $\boldsymbol{H}$-pyrrolato]]]|triboron (5). To a solution of 2,4-dimethyl-3-ethylpyrrole (491.5 mg, $4 \mathrm{mmol}$ ) and 1,3,5-tris(4-formylphenyl)benzene $\left(261.8 \mathrm{mg}, 0.67 \mathrm{mmol}\right.$ ) in anhydrous $\mathrm{CH}_{2} \mathrm{Cl}_{2}(95 \mathrm{~mL}) \mathrm{were}$ added two drops of TFA. The mixture was stirred for $2 \mathrm{~h}$ and a solution of DDQ (457 $\mathrm{mg}, 2 \mathrm{mmol})$ in anhydrous $\mathrm{CH}_{2} \mathrm{Cl}_{2}$ $(50 \mathrm{~mL})$ was added. After stirring for $1 \mathrm{~h}$, diisopropylethylamine $(4 \mathrm{~mL}, 22.9 \mathrm{mmol})$ then $\mathrm{BF}_{3}-\mathrm{Et}_{2} \mathrm{O}(4 \mathrm{~mL}, 31.6 \mathrm{mmol})$ were added. The solution was stirred for $1 \mathrm{~h}$ and water $(100 \mathrm{~mL})$ was added. After filtration of the organic layer through a short pad of silica, the solvent was evaporated and the product purified by column chromatography (gradient heptane$\mathrm{CH}_{2} \mathrm{Cl}_{2}$, from $1: 1$ to $\left.0: 1\right)$ to yield $185 \mathrm{mg}(23 \%)$ of 5: $\mathrm{mp}>300{ }^{\circ} \mathrm{C} \mathrm{dec}$.; ${ }^{1} \mathrm{H}$ NMR $\left(200.13 \mathrm{MHz}, \mathrm{CDCl}_{3}\right) \delta 8.02(\mathrm{~s}, 3 \mathrm{H})$, 7.93 and $7.45\left(\mathrm{AA}^{\prime} \mathrm{XX}^{\prime}, J_{\mathrm{AX}}=8.0,12 \mathrm{H}\right), 2.56(\mathrm{~s}, 18 \mathrm{H}), 2.33(\mathrm{q}, J=7.3,12 \mathrm{H}), 1.41(\mathrm{~s}, 18 \mathrm{H}), 1.00(\mathrm{t}, J=7.3,18 \mathrm{H}) ;{ }^{13} \mathrm{C}$ $\operatorname{NMR}\left(50.32 \mathrm{MHz}, \mathrm{CDCl}_{3}\right) \delta 153.9,141.7,141.1,139.6,138.3,135.4,132.9,130.8,129.1,127.8,125.3,17.1,14.6,12.5$, 12.0; HRMS (LSIMS ${ }^{+}$, mNBA) cacld for $\mathrm{C}_{75} \mathrm{H}_{81} \mathrm{~B}_{3} \mathrm{~F}_{6} \mathrm{~N}_{6}\left(\mathrm{M}^{+}\right) \mathrm{m} / \mathrm{z} 1212.6706$, found 1212.6702.

36. Albota, M. A.; Xu, C.; Webb, W. W. Appl. Opt. 1998, 37, 7352-7356.

37. Rumi, M.; Ehrlich, J. E.; Heikal, A. A.; Perry, J. W.; Barlow, S.; Hu, Z.-Y.; McCord-Maughon, D.; Parker, T. C.; Röckel, H.; Thayumanavan, S.; Marder, S. R.; Beljonne, D.; Brédas, J.-L. J. Am. Chem. Soc. 2000, 122, 9500-9510.

38. (a) Cho, B. R.; Son, K. H.; Sang, H. L.; Song, Y.-S.; Lee, Y.-K.; Jeon, S.-J.; Choi, J. H.; Lee, H.; Cho, M. J. Am. Chem. Soc. 2001, 123, 10039-10045; (b) Abbotto, A.; Beverina, L.; Bozio, R.; Facchetti, A.; Ferrante, C.; Pagani, G. A.; Pedron, D.; Signorini, R. Chem. Commun. 2003, 2144-2145; (c) Mongin, O.; Porrès, L.; Katan, C.; Pons, T.; Mertz, J.; BlanchardDesce, M. Tetrahedron Lett. 2003, 44, 8121-8125; (d) Porrès, L.; Mongin, O.; Katan, C.; Charlot, M.; Pons, T.; Mertz, J.; Blanchard-Desce, M. Org. Lett. 2004, 6, 47-50. 